\title{
Structural change of albite $\left(\mathrm{NaAlSi}_{3} \mathrm{O}_{8}\right)$ melt quenched at high pressure : density and $\mathrm{Al} \mathrm{K}_{\beta} \mathrm{X}$-ray emission
}

\author{
Eiji OHTANi and KazUhiro SUZuKa* \\ Institute of Mineralogy, Fetrology, and Economic Geology, \\ Tohoku University, Sendai 980, Japan \\ "Department of Earth Sciences, Faculty of Science, Nagoya \\ University, Nagoya 464, Japan
}

\begin{abstract}
Density and $\mathrm{Al} \mathrm{K} \mathrm{K}_{\phi} \mathrm{X}$-ray emission band of the albite melts quenched at high pressure up to $8 \mathrm{GPa}$ were measured. The density of the glass increases continuously from $2.473 \mathrm{~g} / \mathrm{cm}^{3}$ at $2 \mathrm{GPa}$ to $2.743 \mathrm{~g} / \mathrm{cm}^{3}$ at $8 \mathrm{GPa}$. The rate of density increase however is not constant but relatively large in the pressure range of 2-6 GPa, suggesting that some structural change of the albite glass takes place in this pressure range. Measurement of $\mathrm{Al} \mathrm{K}_{A}$ emission bands of the albite glass revealed that the emission band shifts towards the higher energy side with increasing pressure. Present measurements of density and $A 1 \mathrm{~K}_{p}$ emission band of the albite glass are consistent with the results of the ${ }^{27} \mathrm{Al}$ NMR spectrometry of the glass (Ohtani et al., 1985), suggesting a coordination change of $\mathrm{Al}^{3+}$ ions in the melt from 4-fold to 6-fold with increasing pressure.
\end{abstract}

\section{Introduction}

Density of magma is one of the most important properties affecting genesis of various magmas and chemical structure of the mantle, since the density of magma controls the modes of fractionation and transportation of the melt from the source. Examples are seen in the lunar and terrestrial cases. Floatation of plagioclase in the dry basaltic magma has been used to explain the lunar anorthositic crust. A possibility of floatation of olivine in the basic and ultrabasic magma at high pressures above $5 \mathrm{GPa}$ has been suggested by various authors (e.g., Stolper et al., 1981; Nisbet and Walker, 1982 ; Ohtani, 1983 ; Rigden et al, 1984). The density crossover and floatation of olivine in the deep upper mantle have important implications to the chemical structure of the earth as have been discussed by various authors (e.g., Ohtani, 1986 ; Agee and Walker, 1988).

A possibility of the coordination change in
$\mathrm{Al}^{3+}$ and $\mathrm{Si}^{4+}$ ions from 4 -fold to 6 -fold has been suggested to explain increase in magma density at high pressure (Waff, 1975). Various works have been made to clarify the structure of the aluminosilicate melts and glasses. $\mathrm{Ku}$. shiro $(1976,1978)$ reported the viscosity of the albite and jadeite melts and density of the glasses quenched at pressures to $2.5 \mathrm{GPa}$. He reported a drastic decrease in viscosity and an increase in the density at around $1 \mathrm{GPa}$.

Recent development of the multi-anvil (MA8) apparatus made it possible to conduct melting experiments at pressures exceeding 10 $\mathrm{GPa}$. Using this technique, Ohtani et al. (1985) synthesized albite glass up to $8 \mathrm{GPa}$. Above this pressure, the glass cannot be obtained even by quenching from the melt. The results of ${ }^{27} \mathrm{Al}$ NMR spectrometry of the glass strongly suggest a structural change of the albite melt at pressures above $6 \mathrm{GPa}$; the coordination change of $\mathrm{Al}^{3+}$ in the glass from 4-fold to 6-fold occurs with increasing pressure. This coordi-

(Manuscript received, July 18, 1989;

accepted for publication, July 28, 1989) 
nation change is similar to that observed in the crystalline phases; albite $\rightarrow$ jadeite +quart $z$.

The other example of the coordination change in $\mathrm{Al}$ is also suggested in the pyrope melt by Fujino et al. (1983) and Irifune and Ohtani (1986). According to these authors, the melting curve of pyrope shows a significant bending at pressure around $6 \mathrm{GPa}$. Since the coordination change of $\mathrm{Al}^{3+}$ ions in the pyrope melt from 4 -fold to 6 -fold causes a volume decrease in the melt, bending of the melting curve of pyrope may be explained by such a structural change of the melt. The change of the quench crystal from aluminous pyroxene to garnet may be also explained by such change in coordination in the pyrope melt (e.g., Irifune and Ohtani, 1986).

In this paper, we present an additional evidence of the coordination change of $\mathrm{Al}^{3+}$ from 4 -fold to 6 -fold in the albite melt by measuring the density and $\mathrm{Al} \mathrm{K}_{\beta} \mathrm{X}$-ray emis. sion band of the melt quenched at various pressures.

\section{Experimental procedure}

A piston cylinder apparatus of the Australian National University was used to synthe. size albite glasses at 2 and $3 \mathrm{GPa}$, whereas the multi-anvil (MA8) high pressure systems of Nagoya University and the Australian National University were used to synthesize the glass at higher pressures.

The platinum capsule was used for the runs made by the piston cylinder apparatus. Various materials such as carbon, boron nitride, and platinum were used as the capsule material for the runs made by the multi-anvil apparatus. Carbon was used as the heating material both for the piston cylinder and multi-anvil systems. Temperature was measured by a $\mathrm{Pt}-\mathrm{Pt} 10 \% \mathrm{Rh}$ thermocouple with a diameter of $0.2 \mathrm{~mm}$ for the piston cylinder apparatus, and a W25\%ReW3\% Re thermocouple with a diameter of 0.2 $\mathrm{mm}$ for the multi-anvil apparatus. The albite crystallized at an atmospheric pressure was used as starting material. It was confirmed as a single phase material of albite using $\mathrm{X}$-ray powder diffraction technique. Details of the description of the high pressure cell of the multi-anvil apparatus are given elsewhere (e.g., Ohtani et al., 1982). The quenching method was adopted to make the albite glass. The temperature was elevated to the desired value above the liquidus temperature of the albite composition at high pressure, and was held at constant for 1 to 2 minutes. The charge was quenched at high pressure by shutting off the electric power supply of the charge. After that the charge was recovered by releasing pressure.

Densities of the albite glasses synthesized at various pressures were measured at room temperature by a floatation method using Cler ici solutions as immersion liquids. The densities of the solutions were calibrated by means of standard glass cubes with known densities.

Al $\mathrm{K}_{\theta}$ emission bands of two albite glasses made at 2 and $8 . \mathrm{GPa}$, crystalline albite, and corundum were measured by using a wavedispersive electron microprobe (JEOL JXA-5A) with a TAP diffraction crystal. The operating conditions were accelerating voltage of $15 \mathrm{kV}$ and a beam current of $0.1 \times 10^{-9} \mathrm{~A}$. Special care was made on precise control and stabilization of beam current. The electron beam was defocused to about 50 microns to prevent contamination and loss of sodium in the glass. Intensities of 60 points across the $\mathrm{Al} \mathrm{K}_{\beta}$ emission band were measured by a step scanning method for 80 seconds in each points.

\section{Results and discussion}

The experimental conditions and results for synthesis of the albite glass were shown in Table 1 and Fig. 1. The glass with albite composition was obtained up to the pressure of 8 GPa. No albite glass was obtained by quen- 
Table 1. Experimental conditions and the resutls for synthesizing the albite glasses at high pressures

\begin{tabular}{|c|c|c|c|c|c|}
\hline Run no. & $\begin{array}{l}\text { Pressure } \\
\text { GPa }\end{array}$ & Temperature & $\begin{array}{c}\text { time } \\
\text { (min.) }\end{array}$ & capsule & products \\
\hline $\mathrm{P} 1 *$ & 2 & 1500 & 5 & Pt & gl \\
\hline $\mathrm{P}^{*}$ & 3 & 1600 & 5 & $\mathrm{Pt}$ & gl \\
\hline N 17 & 6 & 1650 & 1 & $\mathrm{BN}$ & \& 1 \\
\hline N20 & 6 & 1850 & 1 & $\mathrm{BN}$ & gl \\
\hline N2 1 & 6 & 1740 & 2 & carbon & $\mathrm{gl}_{4}$ \\
\hline N23 & 6 & 1740 & 2 & carbon & $\mathrm{gl}]^{*}$ \\
\hline$A 10$ & 6 & 1740 & 2 & carbon & g1 \\
\hline A11 & 6 & 1740 & 2 & carbon & g 1 \\
\hline N15 & 6 & 1500 & 2 & $\mathrm{Pt}$ & jad $+c o e$ \\
\hline N 19 & 6 & 1500 & 2 & $\mathrm{BN}$ & jadt + coe \\
\hline NO & 8 & 2000 & 2 & carbon & gl \\
\hline N26 & 8 & 1970 & 3 & carbon & g $1_{*}^{\#}$ \\
\hline A12 & 8 & 2000 & 2 & carbon & $\mathbf{g l}^{\#}$ \\
\hline $\mathrm{AO}$ & 10 & 2000 & 2 & carbon & $j a d+s t$ \\
\hline
\end{tabular}

gl, glass; jad, jadeite; coe, coesite; st, stishovite.

* piston cylinder apparatus was used in the experiemnt.

\#, crystals are observed at the top and botton parts of the charge due to the temperature gradient of the furnare.

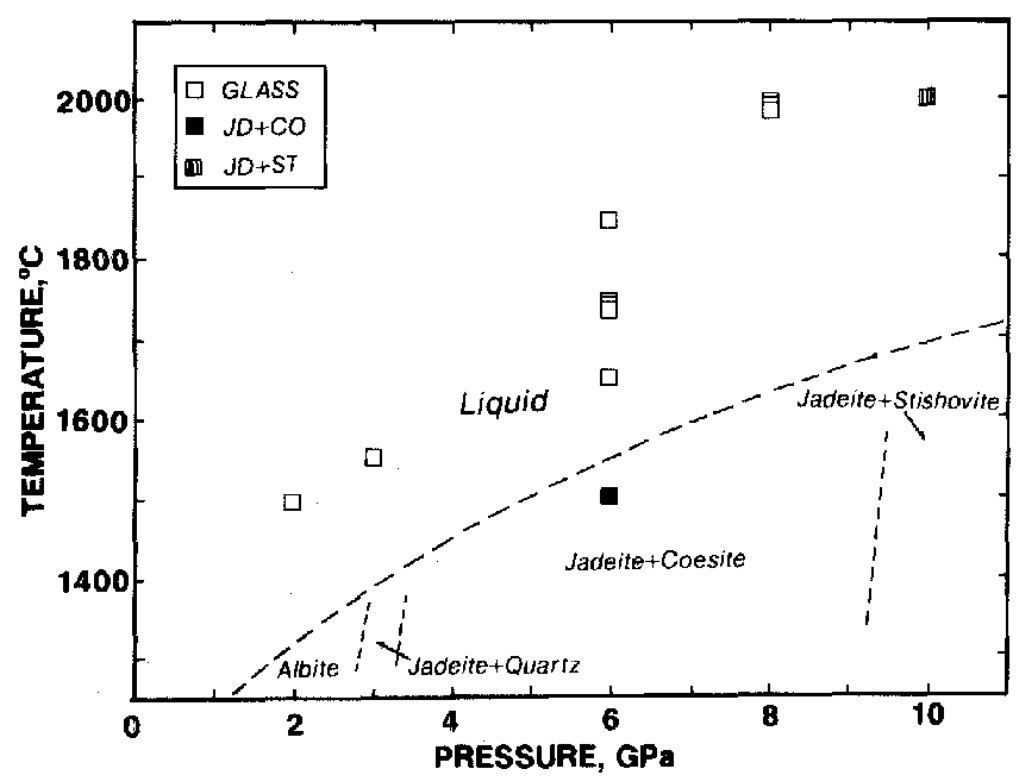

Fig. 1. Experimental conditions for synthesis of the albite glass at high pressures.

ching from $10 \mathrm{GPa}$ and $2000^{\circ} \mathrm{C}$ but the run product was composed of fine grained quench crystals of jadeite and stishovite.

The results of density measurement of the albite glass were summarized in Table 2, and illustrated in Fig. 2. The densities determined by Kushiro (1978) in the lower pressure range up to $2.5 \mathrm{GPa}$ are also illustrated in the same 
Table 2. Results of density measurement of the albite glass at high pressures

\begin{tabular}{|c|c|c|}
\hline $\begin{array}{c}\text { Pregsure } \\
\text { GPe }\end{array}$ & Run no. & $\begin{array}{l}\text { Density of the glass } \\
\text { g/ce }\end{array}$ \\
\hline 2 & P1 & $2.480>d>2.467$ \\
\hline 3 & $\mathrm{P} 2$ & $2.555>d>2.523$ \\
\hline 6 & N21, N23 & $2.678>d_{*}>2.667$ \\
\hline 8 & N26 & $2.769>d^{*}$ \\
\hline & No & $2.769>d>2.717$ \\
\hline
\end{tabular}

* contaningtion of cartan is observed in the glass.

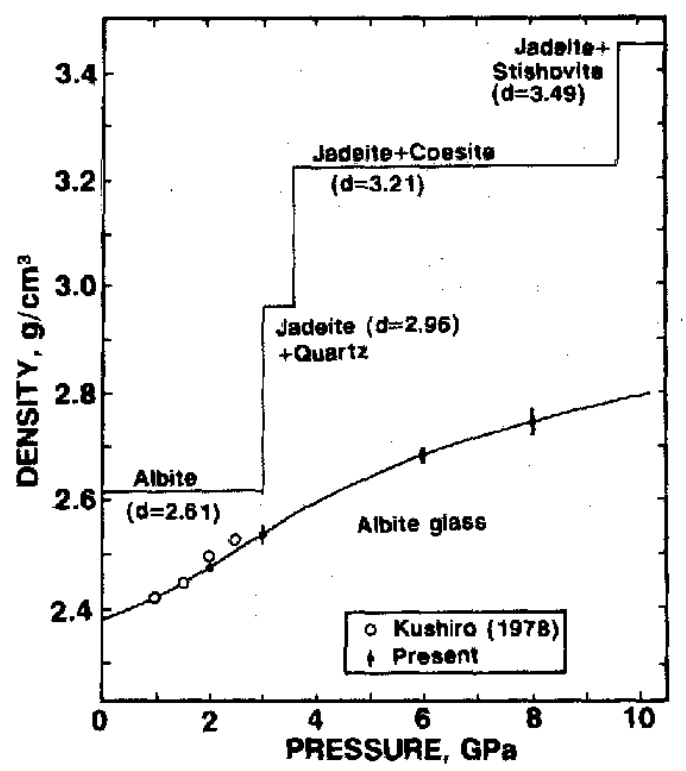

Fig. 2. Density of the albite glass to $8 \mathrm{GPa}$. Previous result by Kushiro (1978) up to $2.5 \mathrm{GPa}$ is also shown in this figure.

figure. The measured density of the albite glass is $2.473 \pm 0.003 \mathrm{~g} / \mathrm{cm}^{3}$ at $2 \mathrm{GPa}, 2.539 \pm$ $0.013 \mathrm{~g} / \mathrm{cm}^{3}$ at $3 \mathrm{GPa}, 2.673 \pm 0.006 \mathrm{~g} / \mathrm{cm}^{3}$ at $6 \mathrm{GPa}$, and $2.743 \pm 0.026 \mathrm{~g} / \mathrm{cm}^{3}$ at $8 \mathrm{GPa}$. Kushiro (1978) reported that the density of the albite glass increases with increasing pressure of quenching from $2.38 \mathrm{~g} / \mathrm{cm}^{3}$ at $1 \mathrm{~atm}$ to 2.525 $\mathrm{g} / \mathrm{cm}^{3}$ at $2.5 \mathrm{GPa}$. Our results indicate continuous increase of the glass density at least up to $8 \mathrm{GPa}$. The rate of density increase, however, is not constant but relatively large between 2 and $6 \mathrm{GPa}$, which suggests that some structural change of the albite glass takes place in this pressure range. This result is consistent with the result of ${ }^{27} \mathrm{Al} \mathrm{NMR}$ spectrometry of the albite glass made by Ohtani et al. (1985). They observed clear evidence of existence of six coordination of $\mathrm{Al}^{3+}$ ions in the albite glass quenched at 6 and $8 \mathrm{GPa}$. The densities of the crystalline phases, such as albite below $3 \mathrm{GPa}$ and jadeite and quartz (and coesite) above this pressure are also shown in Fig. 2. The density of the glass is lower than that of the crystalline phases in all pressure ranges, although the density of the glass increases continuously with increasing pressure, and it approaches to the density of crystalline albite at $c a .3 \mathrm{GPa}$.

Since the $K_{\beta}$ emission band corresponds to an electronic transition from valence state to the ground state for the third-period elements such as Al, the energy shift due to a coordination change should be maximum in this emission band. We measured the $\mathrm{Al} \mathrm{K}_{\beta}$ shift of the albite glasses synthesized at 2 and $8 \mathrm{GPa}$ together with the crystalline albite and corundum. The $\mathrm{Al} \mathrm{K} \mathrm{K}_{p}$ emission spectra of crystalline corundum and albite represent two extremes for rock-forming minerals, i.e. all $\mathrm{Al}^{3+}$ cations occupy 6 -fold coordination in corundum, whereas 4 -fold in albite. Fig. 3 shows the shift of $\mathrm{Al} \mathrm{K}_{\beta}$ emission bands of the albite glasses and crystalline corundum from that of albite. The spectral peak of corundum shifts about $8 \times 10^{-3} \AA$ towards the high-energy side from the peak position of albite. Such displacement of the $\mathrm{Al} \mathrm{K}_{\beta}$ emission band appears to refiect the nature of chemical bond, and coordination change of the $\mathrm{Al}^{3+}$ ions. We observed clear shift of $\mathrm{Al} \mathrm{K}_{s}$ emission band of the glass quenched from $2 \mathrm{GPa}$ and $1500^{\circ} \mathrm{C}$ towards high-energy side from the peak position of crystalline albite. Velde and Kushiro (1978) measured the $\mathrm{Al} \mathrm{K}_{\beta}$ shift of albite glasses synthesized at pressures up to $3 \mathrm{GPa}$, which is consistent with present result of the glass quenched from $2 \mathrm{GPa}$. Further shift of the emission band was observed in the glass quenched from 


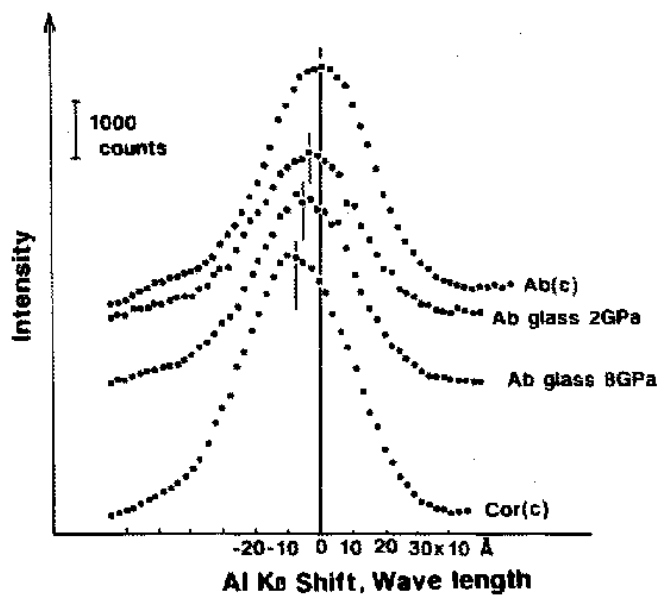

Fig. 3. The $\mathrm{Al} \mathrm{K}_{\theta}$ peak shift of albite glasses synthesized at 2 and $8 \mathrm{GPa}$. The shift of crystalline albite and corundum is also shown in this figure.

$8 \mathrm{GPa}$ and $2000^{\circ} \mathrm{C}$; i.e. the amount of shift of the $\mathrm{Al} \mathrm{K}_{\beta}$ emission band of the albite glass increases with increasing pressure. This observation is consistent with the gradual change of coordination state of $\mathrm{Al}^{3+}$ ions in the albite glass, which has been suggested by the NMR measurement by Ohtani et al. (1985) and the present results of density measurement of the glass.

Kushiro $(1976,1978)$ determined viscosities of the jadeite and albite melts to $2.5 \mathrm{GPa}$, and showed that the viscosities decrease with pressure. They suggested that such decrease in viscosity of the melts is related to the structural change in these melts; i.e. coordination change of $\mathrm{Al}^{3+}$ ions in these melts. Present observation of gradual change of the coordination of $\mathrm{Al}$ ${ }^{3+}$ from 4-fold to 6-fold in the quenched albite melt suggests that viscosity of the melt continues to decrease at least up to $8 \mathrm{GPa}$. Most of the alminosilicate melt, such as natural magmas, may have similar changes in the struc. ture and physical properties under the condjtions of the deep upper mantle.

Acknowledgements: One of the author
(E.O.) is grateful to Mr. W.O. Hibberson of the Australian National University for technical assistance for high pressure experiments using a piston cylinder apparatus. He thanks Dr. $\mathrm{H}$. Sawamoto of Nagoya University for providing an oppotunity to use the high-pressure apparatus. The authors appreciate Professors K-I. Aoki and $\mathrm{K}$. Onuma of Tohoku University for their critical reading and useful comments on the manuscript. Part of the cost of this work was defrayed by the Grant-in-Aid for Scientific Research of Ministry of Education, Science and Culture, Japan Nos. 63540654 and 01420013.

\section{References}

Agee, C.B. and Walker, D. (1988), Mass balance and phase density constraints on early differentiation of chondritic mantle. Earth Planet. Sci. Lett., 90, 144-156.

Fujino, K., Ohtani, E. and Irifune, T. (1983), Crystal chemistry of the pyrope melts at high temperature and pressure and their quenched materials. J. Mineral. Soc. Japan, 16, Spec. issue, no. 1, 231-238 (in Japanese).

Irifune, $\mathrm{T}$. and Ohtani, $\mathrm{E}$ (1986), Melting of pyrope $\mathrm{Mg}_{3} \mathrm{Al}_{2} \mathrm{Si}_{3} \mathrm{O}_{12}$ up to $100 \mathrm{kbar}$ : Possibility of a pressure-induced structural change in pyrope melt. J. Geophys. Res., 91, 9357 9366.

Kushiro, I. (1976), Changes in viscosity and structure of melt of $\mathrm{NaAlSi}_{2} \mathrm{O}_{E}$ composition at high pressure. I. Geophys. Res., 81, 6347-6350.

Kushiro, 1. (1978), Viscosity and structural changes of albite $\left(\mathrm{NaAlSi}_{3} \mathrm{O}_{\mathrm{b}}\right)$ melt at high pressures. Earth Planet. Sci. Lett., 41, 87-90.

Nisbet, E.G. and Walker, D. (1982), Komatijtes and the structure of the Archean mantle. Earth Planet. Sci. Lett., 60, 103-113.

Ohtani, E. (1983), Melting temperature distribution and fractionation in the lower mantle. Phys. Earth Planet. Inter., 33, $12 \cdots 25$.

Ohtani, E. (1985), The primordial terrestrial magma ocean and its implication for the stratification of the mantle. Phys. Earth Planet. Inter, 38, 70-80.

Ohtani, E., Kumazawa, M., Kato, T. and Irifune, T. (1982), Melting of various silicate at elevated pressures. In Adv. Earth Planet. Sci., 12, High Pressure Research in Geophysics, (Akimoto, S. and Manghnani, M.H. Eds.) pp $259 \cdots 270$. 
Ohtani, E., Taulelle, F. and Angell, C.A. (1985) $\mathrm{Al}^{3+}$ coordination changes in liquid aluminosilicates under pressure. Nature, 314, 78-81.

Rigden, S.M., Ahrens, T.J. and Stolper, E. (1984), Densities of liquid silicates at high pressures. Science, 226, 1071 1074.

Stolper, E., M., Walker, D., Hager, B.H. and Hays, J.F. (1981), Melt segregation from partially molten source region: The importance of melt density and source region size. I. Geophys. Res., 86, 6161-6271.

Velde, B, and Kushiro, I. (1978), Structure of sodium alumino-silicate melts quenched at high pressure ; infrared and aluminum $\mathrm{K}$-radiation data. Earth Planet. Sci. Lett., 40, 137140.

Waff, H.S. (1975), Pressure-induced coordination changes in magmatic liquids. Geophys. Res. Lett., 2, 1973.

\section{高圧下で急冷凍結したアルパイトメルト $\left(\mathrm{NaAlSi}_{3} \mathrm{O}_{8}\right)$ の 構造变化：密度及び $\mathrm{Al} \mathrm{K}$ 線の測定}

\section{大谷 栄治・鈴木 和博}

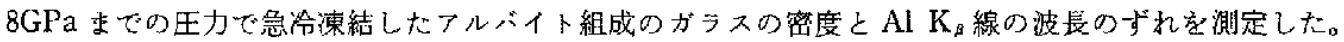
ガラスの密度は2GPa $2.473 \mathrm{~g} / \mathrm{cm}^{3}$ から $8 \mathrm{GPa} の 2.743 \mathrm{~g} / \mathrm{cm}^{3}$ をで連続的に増加するが2GPaか

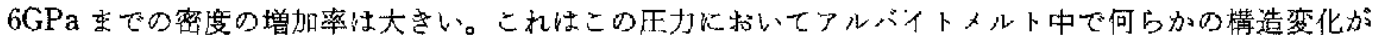

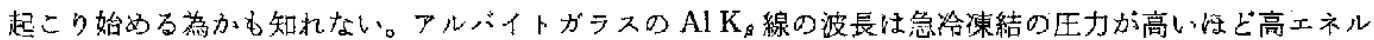

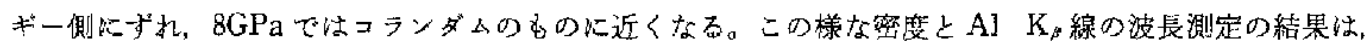

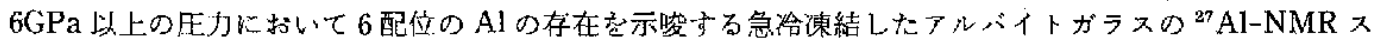
ペクトルの測定結果と矛盾しない。 